\title{
Effects of grape seed proanthocyanidin on Alzheimer's disease in vitro and in vivo
}

\author{
QINGWANG LIAN $^{1 *}$, YONGSHENG NIE $^{1 *}$, XIAOYOU ZHANG ${ }^{2}$, BO TAN $^{1}$, HONGYING CAO $^{1}$, \\ WENLING CHEN $^{2}$, WEIMING GAO ${ }^{2}$, JIAYI CHEN ${ }^{1}$, ZHIJIAN LIANG ${ }^{1}$, HUANGLING LAI $^{1}$, \\ SIMING HUANG ${ }^{1}$, YIFEI XU ${ }^{1}$, WEIWEN JIANG ${ }^{1}$ and PING HUANG ${ }^{1}$ \\ ${ }^{1}$ Department of Pharmacology Teaching and Research, College of Chinese Medicine, \\ Guangzhou University of Chinese Medicine, Guangzhou, Guangdong 510006; \\ ${ }^{2}$ BannerBioNutraceuticals Inc., Shenzhen, Guangdong 518057, P.R. China
}

Received March 16, 2015; Accepted April 21, 2016

DOI: $10.3892 /$ etm.2016.3530

\begin{abstract}
Grape seed proanthocyanidin (GSPA) consists of catechin, epicatechin and epicatechin gallate, which are strong antioxidants that are beneficial to health and may attenuate or prevent Alzheimer's disease (AD). In the present study, the effects of GSPA on pheochromocytoma (PC12) cell viability were determined using cell counting kit- 8 and lactate dehydrogenase (LDH) assays, whereas apoptosis and mitochondrial membrane potential $(\Psi \mathrm{m})$ were measured via flow cytometry analysis. The effect of GSPA administration on the behavior and memory of amyloid precursor protein (APP)/presenilin-1 (PS-1) double transgenic mice was assessed using a Morris water maze. APP A $\beta$ peptides and tau hyperphosphorylation were examined by western blotting; whereas the expression levels of PS-1 were evaluated by reverse transcription-quantitative polymerase chain reaction and compared with pathological sections stained with hematoxylin-eosin and Congo red. Data from the in vitro experiments demonstrated that GSPA significantly alleviated A $\beta 25-35$ cytotoxicity and LDH leakage ratio, inhibited apoptosis and increased $\Psi \mathrm{m}$. The findings from the in vivo experiments showed a significant enhancement in cognition and spatial memory ability, an improvement in the pathology of APP and tau protein and a decrease in PS-1 mRNA expression levels. Therefore, the results of the present study indicated that GSPA may be a novel therapeutic strategy for the treatment of AD or may, at the very least, improve the quality of life of patients with AD.
\end{abstract}

Correspondence to: Dr Ping Huang, Department of Pharmacology Teaching and Research, College of Chinese Medicine, Guangzhou University of Chinese Medicine, 232 Wai Huan East Road, Guangzhou, Guangdong 510006, P.R. China

E-mail: hping331@126.com

*Contributed equally

Key words: Alzheimer's disease, grape seed proanthocyanidin, oxidative stress, $\mathrm{A} \beta$ precursor protein, tau protein, presenilin-1

\section{Introduction}

Alzheimer's disease (AD) is a progressive neurodegenerative disorder which is characterized by the loss of cognition and memory capacity, and decreased visual-spatial skills. Pathologically, AD is characterized by increased amyloid-beta $(A \beta)$, hyperphosphorylation and the aggregation of tau protein $(1,2)$. A $\beta$ peptides are produced from amyloid precursor protein (APP) when it is cleaved by $\beta$ - and $\gamma$ - secretases into amino acid peptides within the cerebral cortex and hippocampus (3). Accumulation of insoluble $A \beta$ induces the aggregation of peptide-forming amyloid fibrils, which have been demonstrated to be neurotoxic in vitro and vivo (4). The $\gamma$-secretase enzyme induces intramembrane cleavage of APP, and is part of a multi-subunit intramembranous protein complex that includes PS-1 $(5,6)$. Moreover, excessive deposition of $A \beta$ stimulates microtubule-associated protein tau aggregation into abnormally hyperphosphorylated tau, which assemble into paired helical filaments (PHFs) are significantly increased in patients with $\mathrm{AD}(7)$.

$A \beta$ may trigger neurodegeneration via oxidative stress. Previous studies have demonstrated that the production of excessive reactive oxygen species (ROS) and signs of oxidative stress were detected in the AD brain (8-11). In addition, it has been demonstrated that oxidative stress has a critical role in $A \beta$-mediated neuronal cytotoxicity by triggering or facilitating neurodegeneration (12). Oxidative damage may initiate during the earlier stages of AD and induce amnestic mild cognitive impairment and a reduced antioxidant capacity (13-15). Furthermore, oxidative damage is associated with apoptosis, mitochondrial membrane damage and mitochondrial dysfunction (16); therefore, reducing oxidative stress may decrease A $\beta$-induced neurotoxicity (17). We hypothesized that strong antioxidants were capable of attenuating oxidative stress, and may represent a therapeutic strategy to treat $A \beta$-induced neurotoxicity and improve the symptoms of AD.

A previous study in transgenic animals have shown that moderate consumption of red wine may alleviate AD-like neuropathology and cognitive deterioration (18). Furthermore, Ono et al (19) demonstrated that a specific grape-derived polyphenolic extract (GSPE) reduced A $\beta$ peptide oligomerization 
and fibril development in vitro. Previous studies have also indicated that families of polyphenols may interfere with tau fibril formation in vitro and in cultured cells $(20,21)$. Notably, it has been demonstrated that GSPE attenuates the aggregation of tau-mediated neuropathology in the brain of the Thy-1 mutated human tau mouse model of tauopathy (22). GSPE is a complex mixture of proanthocyanidin monomers, oligomers and polymers, which are strong antioxidants; therefore, the antioxidant activities of these compounds may be beneficial to patients with $\operatorname{AD}(23,24)$. We hypothesize that using monomers of aqueous grape seed proanthocyanidin (GSPA) may induce a stronger antioxidant effect than a complex mixture of GSPE. This may provide a new strategy for the treatment of $\mathrm{AD}$ or, may at least improve the quality of life of patients with AD.

\section{Materials and methods}

Ethics statement. All experimental protocols were approved by the Ethics Committee of the Animal Center of Guangzhou University of Traditional Chinese Medicine (Guangzhou, China).

Grape seed extraction. Grape seed plant material was purchased (Biovin Naturprodukte, Ilbesheim, Germany), which was extracted for $2 \mathrm{~h}$ in an ethanol:water $(13: 7$; v/v) mixture. Following filtration of the extracting solution, the filtrate was recovered using ethanol and ultrafiltered. The eluent was concentrated by rapid drying with hot gas, and the resulting eluate was lyophilized and reconstituted in phosphate-buffered saline (PBS) at various concentrations for biological assays and is referred to as aqueous GSPA. High-performance liquid chromatography (HPLC) analysis quantification of GSPA is shown in Fig. 1. Preliminary studies have demonstrated that GSPA is non-toxic to normal C57 mice at single doses $(\leq 7000 \mathrm{mg} / \mathrm{kg})$ within the first 14 days (data not shown).

Reagents. Beta-amyloid peptide (A $\beta 25-35)$ and rhodamine 123 were purchased from Sigma-Aldrich (St. Louis, MO, USA). Dulbecco's Modified Eagle Medium (DMEM) and PBS were obtained from Hyclone (GE Healthcare Life Sciences, Logan, UT, USA). Fetal bovine serum (FBS), horse serum (HS), $0.25 \%$ trypsin and phenol red were purchased from Gibco (Thermo Fisher Scientific, Waltham, MA, USA). Annexin V-fluorescein isothiocyanate (FITC) and propidium iodide (PI) were purchased from eBioscience, Inc., (San Diego, CA, USA). Cell counting kit-8 (CCK-8) was purchased from Dojindo Molecular Technologies, Inc., (Kumamoto, Japan). Penicillin and streptomycin were purchased from Solarbio Science \& Technology Co., Ltd., (Beijing, China). Lactate dehydrogenase (LDH) assay kit was purchased from Nanjing Jiancheng Bioengineering Institute (Nanjing, China). Immobilon-P polyvinylidene difluoride membrane was purchased from EMD Millipore (Billerica, MA, USA). Anti-APP antibody (cat. no. ab2072) and phosphorylated (phospho) tau (cat. no. s396) were purchased from Abcam (Cambridge, MA, USA). Anti- $\beta$-actin (cat. no. sc-47778) was purchased from Santa Cruz Biotechnology, Inc., (Dallas, Texas, USA). Horseradish peroxidase (HRP)-conjugated anti-mouse
IgG (cat. no. PA43002) was purchased from Kirkegaard \& Perry Laboratories, Inc., (Gaithersburg, Maryland, USA). Donepezil hydrochloride was purchased from Eisai China Inc., (Shanghai, China). All other reagents and chemicals used in the present study were of analytical grade.

Animals and drug administration. A total of 30 APP/PS1 male heterozygous mice [Swedish mutant $\beta$-amyloid precursor protein, a 9 exon presenilin 1 gene mutation; license number: SCXK (Su) (2010-0001)], aged 5-6 months and weighing $22 \pm 0.94 \mathrm{~g}$, were purchased from Nanjing University (Nanjing, China), of which 24 were APP/PS1 double transgenic mice and remaining 6 were normal. Mice were housed according to a 12-h light-dark cycle with ad libitum access to food and water. Mice were randomly divided into the following five groups: Control group [6 normal mice administered saline by oral gavage (OG) for 2 months]; APP/PS1 model group ( 6 double transgenic mice administered saline by OG for 2 months); APP/PS1 donepezil control group (6 double transgenic mice administered donepezil hydrochloride by OG at $2 \mathrm{mg} / \mathrm{kg} / \mathrm{day}$ for 2 months); low dose APP/PS1-treated group ( 6 double transgenic mice administered GSPA by OG at $50 \mathrm{mg} / \mathrm{kg} /$ day for 2 months); and high dose APP/PS1-treated group ( 6 double transgenic mice administered GSPA by OG at $100 \mathrm{mg} / \mathrm{kg} /$ day for 2 months).

Preparation of aggregated A $\beta 25-35$. A $\beta 25-35$ peptide was dissolved in deionized distilled water at $1 \mathrm{mM}$ and incubated for 7 days at $37^{\circ} \mathrm{C}$ to induce aggregation, as previously described $(10,25,26)$. Following aggregation, the solution was stored at $-20^{\circ} \mathrm{C}$ until use.

Cell culture and treatment. Pheochromocytoma (PC12) cells were obtained from the College of Pharmacy of Sun Yat-Sen University (Guangzhou, China). Cells were seeded in $25 \mathrm{~cm}^{2}$ flasks at a density of $1 \times 10^{5}$ cells and maintained in DMEM supplemented with $100 \mathrm{U} / \mathrm{ml}$ penicillin, $100 \mathrm{U} / \mathrm{ml}$ streptomycin, $5 \% \mathrm{HS}$ and $5 \% \mathrm{FBS}$ at $37^{\circ} \mathrm{C}$ in a humidified atmosphere of $95 \%$ air and $5 \% \mathrm{CO}_{2}$. At $80 \%$ confluence, cells were subcultured for $24 \mathrm{~h}$ in the same conditions prior to incubation with various concentrations of GSPA $(12.5,25,50$ and $100 \mu \mathrm{g} / \mathrm{ml})$ for $2 \mathrm{~h}$. Following this, $20 \mu \mathrm{M} \mathrm{A} \beta 25-35$ was added to the culture medium for an additional $24 \mathrm{~h}$ prior to the initiation of the assays.

Cell viability assay. Cell viability was evaluated via quantitative colorimetric CCK-8 and $\mathrm{LDH}$ assays following treatment with GSPA, A $\beta 25-35$ or combination therapy with both. Briefly, cells were seeded onto 96-well culture plates at $1 \times 10^{4}$ cells/well in DMEM and, following drug treatment, the cell cultures were supplemented with $10 \mu \mathrm{l} /$ well CCK-8 solution and incubated at $37^{\circ} \mathrm{C}$ for $1 \mathrm{~h}$. Optical density of each well was determined at $450 \mathrm{~nm}$ using a microplate reader (FSA-1510; Thermo Fisher Scientific, Inc.). Cell viability was expressed as a percentage of the untreated controls.

For the LDH assay, $150 \mu 1$ incubation medium was collected from each well and added to an LDH assay solution. LDH activity was measured using a microplate reader, according to the manufacturer's instructions (Nanjing Jiancheng Bioengineering Institute). 
Assessment of apoptosis. Annexin V-FITC and PI staining was used to detect apoptosis and necrosis following drug treatment. During the early stages of apoptosis, membrane phosphatidylserine (PS) is translocated from the inner lipid layer of the plasma membrane to the outer layer in various cell types, including PC12 cells (27). Once on the cell surface, PS can be easily detected by staining with annexin, which is a protein with a strong affinity to PS. Annexin was conjugated to the highly photostable FITC. Cells in the late stage of apoptosis were measured by conventional PI staining. The assay was directly performed on live cells and the relative number of early and late apoptotic cells was measured using flow cytometry. Following drug treatment, cells $\left(1 \times 10^{5}\right.$ cells/plate) were washed with PBS, harvested and subsequently centrifuged at $2,000 \mathrm{x} \mathrm{g}$ for $5 \mathrm{~min}$ at $37^{\circ} \mathrm{C}$. Cells were then resuspended in $1000 \mu \mathrm{l}$ buffer and an aliquot $(190 \mu \mathrm{l})$ of the cell suspension was mixed with $5 \mu \mathrm{l}$ Annexin V-FITC and $10 \mu \mathrm{l}$ PI and incubated for $25 \mathrm{~min}$ at room temperature in the dark. Cell staining was measured with a fluorescence-activated cell sorting (FACS) flow cytometer (BD FACSCanto II; BD Biosciences, San Jose, CA, USA) at $E x=488 \mathrm{~nm}$ and $E m=530 \mathrm{~nm}$. Cell apoptosis was expressed as the percentage of control cultures incubated with Annexin V-FITC + PI, but not treated with GSPA or A $325-35$.

Measurement of mitochondrial membrane potential ( $\Psi \mathrm{m})$. Mitochondrial $\Psi \mathrm{m}$ was measured using rhodamine 123. Rhodamine 123 can enter the mitochondrial matrix and induce photoluminescent quenching that is dependent on mitochondrial transmembrane potential (28). Following drug treatment, PC12 cells were incubated with $5 \mathrm{mg} / 1$ rhodamine 123 for $30 \mathrm{~min}$ at $37^{\circ} \mathrm{C}$ in the dark. Subsequently, cells were washed three times with PBS and the fluorescence emission intensity was measured with a flow cytometer at $\mathrm{Ex}=488 \mathrm{~nm}$ and $\mathrm{Em}=535 \mathrm{~nm}$. Intensity of fluorescence emission was expressed as the percentage of control cells incubated in rhodamine 123 but not treated with GSPA or A $\beta 25-35$.

Morris water maze (MWM) test. The MWM test was used to assess alterations in the behavior of the mice, as previously described (29). The maze was a circular pool (diameter, $160 \mathrm{~cm}$; depth, $50 \mathrm{~cm}$ ) filled with water at $24-26^{\circ} \mathrm{C}$ to a depth of $35 \mathrm{~cm}$. Soluble skim milk was used to ensure the water was opaque. A hidden platform (diameter, $8 \mathrm{~cm}$ ) was submerged $\sim 2 \mathrm{~cm}$ below the surface of the water in the center of the designated target quadrant. Visual cues were placed around the water maze. The two phases of the MWM tests included an oriented navigation trial and a spatial probe trial. Oriented navigation trials were conducted four times/day for five days. In each trial, mice were placed into the water in a different quadrant and given $120 \mathrm{sec}$ to find the platform and remain on the platform for $10 \mathrm{sec}$. If the mouse failed to locate the platform within the given time, it was guided to the platform and remained on the platform for $10 \mathrm{sec}$. During the oriented navigation trials, behavior and the time required for the mouse to locate the hidden platform (escape latency) were recorded via a computerized video tracking system. Mice that did not locate the hidden platform within the allotted time scored a maximum of $120 \mathrm{sec}$. During the spatial probe trials, the platform was removed and the mice were allowed to swim freely for $120 \mathrm{sec}$. The mean search time each mouse spent in the target quadrant was recorded to assess spatial memory ability.

Hematoxylin-eosin and Congo red staining. All mice were sacrificed with an overdose $(150 \mathrm{mg} / \mathrm{kg})$ of pentobarbital sodium (Sigma-Aldrich, St. Louis, MO, USA). Paraffin-embedded tissue sections were placed on slides, dewaxed and stained with hematoxylin for $3 \mathrm{~min}$, followed by eosin staining for $3 \mathrm{sec}$. Sections were then dehydrated with alcohol, fixed with xylene and sealed. Hippocampal histopathological abnormalities were investigated under a light microscope. The number of cells in the hippocampal CA1 region of each section was examined by three independent pathologists in a blinded manner. The average number of cells was used as the final result.

Three slides from each mouse were rehydrated in a graded alcohol series, immersed in hematoxylin for $2 \mathrm{~min}$, and subsequently submerged in hydrochloric acid for $10 \mathrm{sec}$. Following this, sections were rinsed in running tap water for $10 \mathrm{~min}$ until they turned blue, washed twice in distilled water and stained with Congo red for $40 \mathrm{~min}$ at room temperature prior to rinsing in running tap water. Subsequently, the slides were submerged in lithium carbonate for $5 \mathrm{sec}$ and washed in running tap water. Alcohol (80\%) was used to differentiate between true staining and nonspecific background staining. Sections were rinsed in running tap water for $10 \mathrm{~min}$, cleared in xylene, and covered with neutral gum. Predetermined marks were used to position the light microscope field for image collection (Olympus BX41; Olympus Corporation, Tokyo, Japan). For blind analysis, this and all subsequent steps were performed by an investigator unaware of the treatment condition of each sample using an additional numbering code. Images were collected using the x20 objective (providing an overall magnification of x200) of the region of interest. For ease of processing, all images were of the same size. The intensity of each object was analyzed using Image $\mathrm{J}$ software version 1.37 software.

Western blot analysis. The right hippocampus was harvested from the mice and stored in liquid nitrogen. Following tissue homogenization, total proteins were extracted using the total protein extraction reagents kit (EMD Millipore). Protein concentration was measured using a bicinchoninic acid protein assay kit (Qian Chen Biotechnology Company, Shanghai, China). Protein samples $(20 \mu \mathrm{l})$ were separated by SDS-PAGE for $70 \mathrm{~min}$ at $90 \mathrm{~V}$ and transferred to PVDF membranes using transblotting apparatus (Bio-Rad Laboratories, Inc., Hercules, CA, USA) for $90 \mathrm{~min}$ at $90 \mathrm{~V}$. Membranes were blocked with $5 \%(\mathrm{w} / \mathrm{v})$ skim milk at room temperature for $30 \mathrm{~min}$ and subsequently incubated at room temperature for $90 \mathrm{~min}$ with anti-APP antibody $(1: 1,000)$ and phospho tau $(1: 2,000)$ primary antibodies. The immunolabeled membranes were washed once with Tris-buffered saline with Tween 20 (TBS-T) for $30 \mathrm{~min}$ followed by three separate washes (10 min/wash). Following this, the membranes were probed with a HRP-conjugated secondary antibody $(1: 2,000)$ at room temperature for $1 \mathrm{~h}$. To verify equal protein loading, the membranes were incubated with monoclonal $\beta$-actin antibody $(1: 1,500)$ at room temperature and then the same HRP-conjugated goat anti-mouse IgG $(1: 2,000)$ at $37^{\circ} \mathrm{C}$ for $2 \mathrm{~h}$. The membrane was washed three times with TBS-T and the protein bands were visualized 
with enhanced chemiluminescence western blotting detection reagents. The intensity of each target protein band was analyzed using Image J software version 1.37 (National Institutes of Health, Bethesda, MA, USA) and expressed relative to $\beta$-actin density.

Reverse transcription-quantitative polymerase chain reaction (RT-qPCR). Hippocampal tissue was homogenized using an automated homogenizer at $4^{\circ} \mathrm{C}$. Total RNA was harvested from the hippocampus, isolated using TRIzol reagent and reverse transcribed into cDNA using RT-PCR kits according to the manufacturer's instructions. The contents of the reaction mixture were as follows: $2 \mu 1$ total RNA, $1 \mu \mathrm{l}$ Oligo dT, $9 \mu 1$ DEPC-treated water, $4 \mu 1$ XX reaction buffer, $1 \mu 1$ Ribolcok TMRNase inhibitor, $2 \mu 110 \mathrm{mM}$ dNTP and $1 \mu 1$ RevertAid TMV reverse transcriptase. cDNA was amplified by RT-qPCR on an ABI Prism 7500 system (Thermo Fisher Scientific, Inc.) using $12.5 \mu \mathrm{l} 2 \mathrm{X}$ Maxima SYBR Green/Rox Master Mix reagent, $0.75 \mu \mathrm{l}$ forward primer, $0.75 \mu \mathrm{l}$ reverse primer, $2 \mu \mathrm{l}$ template DNA and $9 \mu \mathrm{l}$ nuclease-free water. Expected RT-qPCR product sizes and the primers used in this study are presented in the Table I. Samples were inactivated for $2 \mathrm{~min}$ at $50^{\circ} \mathrm{C}$ prior to hot-start amplification. Amplification cycles were performed as follows: $95^{\circ} \mathrm{C}$ for $15 \mathrm{~min}$, followed by 40 cycles of $55^{\circ} \mathrm{C}$ for $15 \mathrm{sec}, 60^{\circ} \mathrm{C}$ for $30 \mathrm{sec}$ and $72^{\circ} \mathrm{C}$ for $30 \mathrm{sec}$. RT-qPCR was repeated in triplicate. Data from the reactions were collected and analyzed using ABI Prism 7500 software. Relative gene expression levels were calculated according to the $2^{-\Delta \Delta \mathrm{Cq}}$ method and were normalized to $\beta$-actin expression in each sample (30). Statistical analysis. Data are expressed as means \pm standard error of the mean. Multiple group comparisons were performed using one-way analysis of variance followed by Dunnett's test for pair-wise comparisons between groups. SPSS 15.0 (SPSS, Inc., Chicago, IL, USA) was used for all statistical analyses in this study. $\mathrm{P}<0.05$ was considered to indicate a statistically significant result.

\section{Results}

HPLC analysis of GSPA. Normal-phase-HPLC chromatograms of GSPA are presented in Fig. 1A. The most abundant peaks of the most active subfractions were purified using HPLC in isocratic elution mode to yield active fractions. Catechin retention time was $25.6 \mathrm{~min}$, whereas epicatechin retention time was $32.8 \mathrm{~min}$. Normal-phase-HPLC chromatograms of catechin and epicatechin are presented in Fig. 1B. The results suggest that catechin and epicatechin are abundant in GSPA.

Effect of GSPA on PC12 cell viability. Cell viability was assessed using a CCK-8 reduction assay (Fig. 2). Treatment of PC12 cells with $<200 \mu \mathrm{g} / \mathrm{ml}$ GSPA alone for $24 \mathrm{~h}$ was demonstrated to be non-toxic. CCK- 8 reduction is linearly correlated with cell number and only $200 \mu \mathrm{g} / \mathrm{ml}$ GSPA, which was the highest concentration tested, reduced the viable cell number ( $\sim 92 \%$ of control). The results suggest that GSPA $<200 \mu \mathrm{g} / \mathrm{ml}$ is non-toxic to PC12 cells.

Treatment with GSPA protects against A $\beta 25$-35-induced cytotoxicity in PC12 cells. Treatment of PC12 cells with $20 \mu \mathrm{M} \mathrm{A} \beta 25-35$ for $24 \mathrm{~h}$ significantly reduced the estimated
Table I. Primers for reverse transcription-quantitative polymerase chain reaction analysis of $\beta$-actin and presenilin- 1 .

\begin{tabular}{ll}
\hline cDNA product & \multicolumn{1}{c}{ Sequence (5'-3') } \\
\hline$\beta$-actin & Forward, CTGGTGAAACTCTGCGTCTG \\
& Reverse, AGAACAAGCGCCATACGACT \\
Presenilin-1 & Forward, GTGGTGAAACTCTGCGTCTG \\
& Reverse, AGAACAAGCGCCATACGACT
\end{tabular}

viable cell number to $65.9 \%$ of the control ( $\mathrm{P}<0.01$; Fig. $3 \mathrm{~A}$ ). However, when PC12 cells were pretreated for $2 \mathrm{~h}$ with GSPA $(12.5,25,50$ and $100 \mu \mathrm{g} / \mathrm{ml}$, respectively) A $\beta 25-35$-induced cytotoxicity was significantly reduced to $69.5 \%$ of control viability at $12.5 \mu \mathrm{g} / \mathrm{ml}(\mathrm{P}<0.05), 70.7 \%$ at $25 \mu \mathrm{g} / \mathrm{ml}(\mathrm{P}<0.01)$, $84.8 \%$ at $50 \mu \mathrm{g} / \mathrm{ml}(\mathrm{P}<0.01)$, and $86 \%$ at $100 \mu \mathrm{g} / \mathrm{ml}(\mathrm{P}<0.01)$.

Analysis of the levels of LDH released into the culture media from dead/dying cells confirmed that GSPA partially blocked A $325-35$-induced cytotoxicity (Fig. 3B). Compared with the control group, A $\beta 25-35$ treatment significantly increased LDH leakage $(\mathrm{P}<0.01)$ and this release was significantly attenuated by GSPA administration $(\mathrm{P}<0.01)$. The results suggest that GSPA is able to partially block A $\beta 25-35$-induced cytotoxicity.

Treatment with GSPA reduces A $\beta 25-35$-induced apoptosis. Annexin V-FITC and PI double staining can distinguish healthy cells (annexin-negative; PI-negative) from early apoptotic (annexin-positive; PI-negative), late apoptotic (annexin-positive; PI-positive), and necrotic (annexin-negative; PI-positive) cells (31). The apoptotic (early + late) rate of PC12 cells following A $\beta 25-35$ treatment was $45.1 \%$; however, GSPA pretreatment significantly reduced the apoptotic rate to $39.9 \%$ at $50 \mu \mathrm{g} / \mathrm{ml}(\mathrm{P}<0.05)$ and $33.9 \%$ at $100 \mu \mathrm{g} / \mathrm{ml}(\mathrm{P}<0.01)$. The healthy cell rate following A $\beta 25-35$ treatment was $53.3 \%$. However, GSPA pretreatment increased the healthy cell rate to $60 \%$ at $50 \mu \mathrm{g} / \mathrm{ml}$ and $65.1 \%$ at $100 \mu \mathrm{g} / \mathrm{ml}$ (both $\mathrm{P}<0.01$, as compared with A $\beta 25-35$ alone) (Fig. 4). The results suggest that GSPA reduces A $325-35$-induced apoptosis.

Treatment with GSPA reverses depolarized mitochondrial $\Psi m$ in PC12 cells. Cells exposed to $20 \mu \mathrm{M}$ A $325-35$ for $24 \mathrm{~h}$ exhibited significantly depolarized mitochondrial $\Psi \mathrm{m}$ (45\% loss of $\Psi \mathrm{m} ; \mathrm{P}<0.01$, as compared with control group), which indicated impending apoptosis or necrosis (Fig. 5). Pretreatment with GSPA partially reversed the response to subsequent treatment with $20 \mu \mathrm{M}$ A $\beta 25-35$ for $24 \mathrm{~h}$. Rhodamine 123 fluorescence percentage rate was $56 \%$ at $50 \mu \mathrm{g} / \mathrm{ml}$ and $88.3 \%$ at $100 \mu \mathrm{g} / \mathrm{ml}$ (both $\mathrm{P}<0.001$, as compared with the $\mathrm{A} \beta 25-35$ model group). The results suggest that GSPA is able to reverse depolarized mitochondrial $\Psi \mathrm{m}$ in PC12 cells.

Treatment with GSPA improves learning ability in APP/PS1 double transgenic mice. The results of the oriented navigation trials are presented in Table II. No significant differences in swim speed were detected among the groups (data not shown). The results of the MWM test demonstrated that APP/PS1 mutant mice exhibited significantly impaired learning ability in the water maze, as compared with the control group from 
A

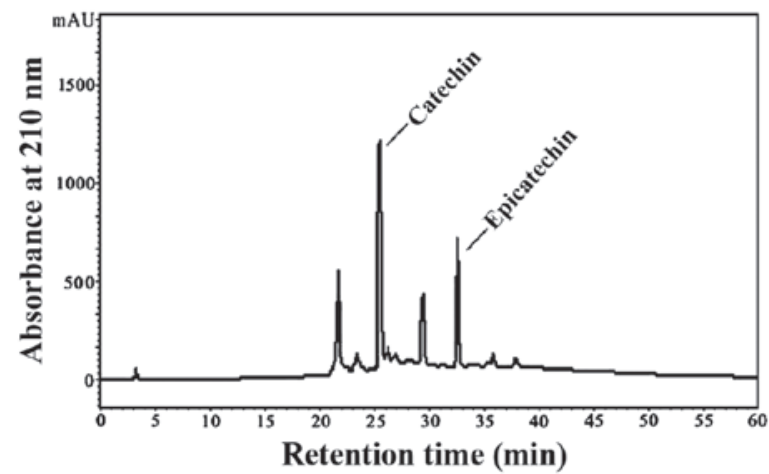

B

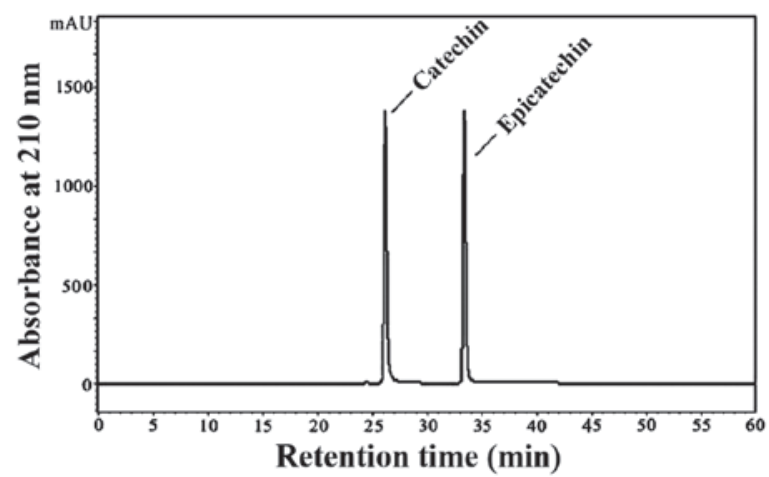

Figure 1. HPLC analysis of GSPA. (A) Normal-phase-HPLC chromatograms of GSPA. (B) Normal-phase-HPLC chromatograms of catechin and epicatechin. HPLC, high-performance liquid chromatography; GSPA, grape seed proanthocyanidin.

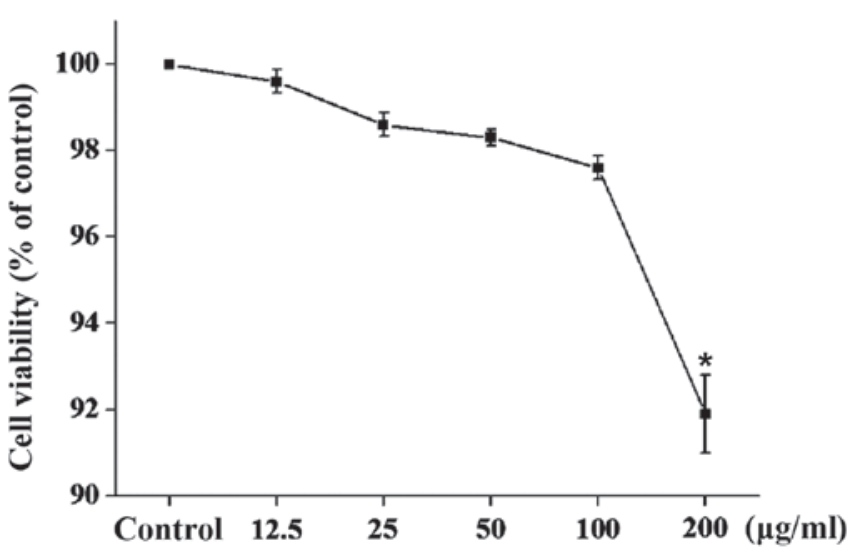

Figure 2. Grape seed proanthocyanidin treatment was non-toxic to PC12 cells at concentrations $<200 \mu \mathrm{g} / \mathrm{ml}$. Cell viability was assessed using a cell counting kit- 8 reduction assay and expressed relative to untreated control cultures (100\% viability). Data are expressed as the mean \pm standard error of the mean $(n=6) .{ }^{*} \mathrm{P}<0.05$, compared with the control group.

days $1-5(\mathrm{P}<0.05)$. The results of the spatial probe trials are shown in Fig. 6. As compared with the control group, the APP/PS model group exhibited significantly increased escape latency times $(\mathrm{P}<0.01)$ and a significantly decreased number of platform crossings $(\mathrm{P}<0.01)$. The APP/PS1 donepezil group exhibited significantly decreased latency $(\mathrm{P}<0.01)$ and a significantly increased number of platform crossings $(\mathrm{P}<0.01)$, as compared with the APP/PS1 model group. The APP/PS1-treated low and high dose GSPA groups also exhibited significantly reduced latency periods $(\mathrm{P}<0.05)$. Notably, the high dose GPSA group exhibited an increased number of platform crossings, as compared with the low dose group. Therefore, these results suggested that GSPA treatment may improve the learning ability of mice in a concentration-dependent manner. The results suggest that GSPA is able to improve learning ability in APP/PS1 double transgenic mice.

Treatment with GSPA alleviates amyloid plaques in the hippocampus of APP/PS1 double transgenic mice. $\mathrm{HE}$ staining revealed no remarkable neuronal abnormalities in the hippocampus of mice in the control group. The pyramidal cells in the CA1 region were arranged neatly and tightly, the
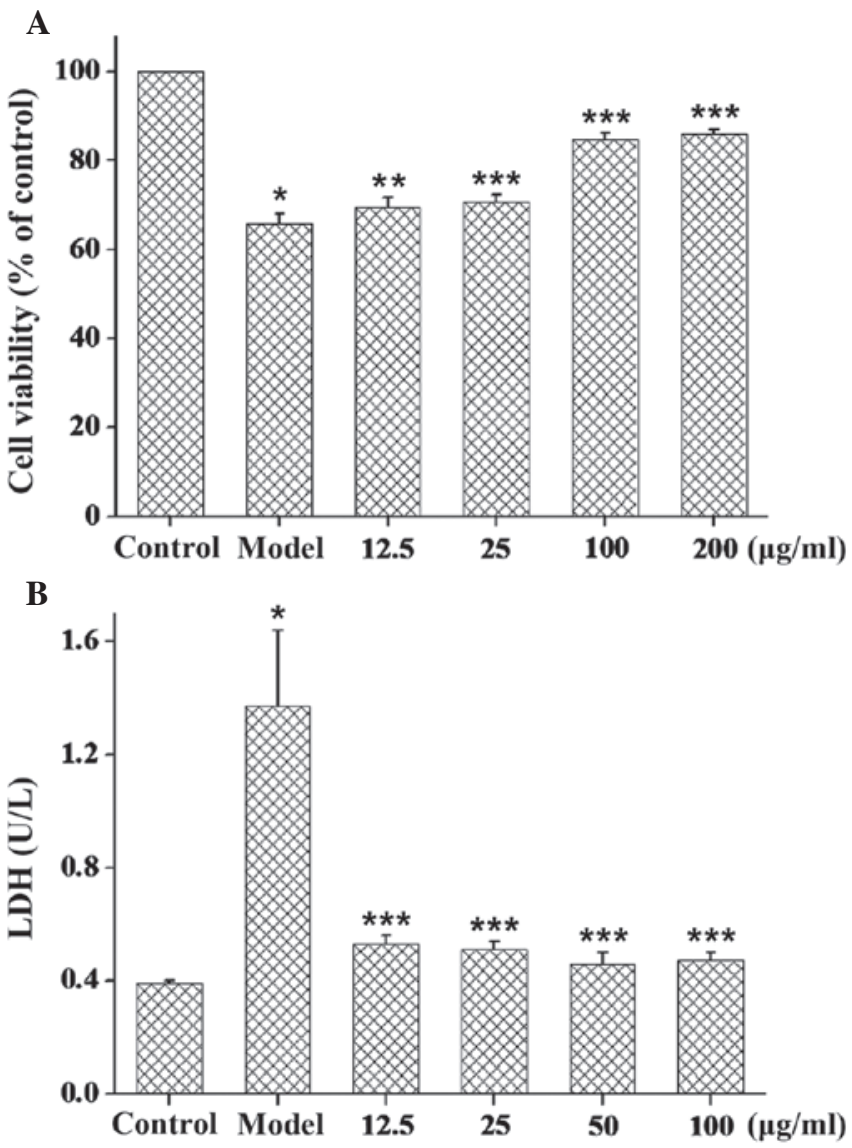

Figure 3. Grape seed proanthocyanidin partially reversed $A \beta 25-35$-induced cytotoxicity. (A) Cell viability was assessed using a cell counting kit- 8 reduction assay. (B) Cell death was determined by $\mathrm{LDH}$ release into the culture media during amyloid $\beta 25-35$ treatment. Data are expressed as the mean \pm standard error of the mean $(n=6)$. ${ }^{*} P<0.01$, as compared with the control group; ${ }^{* *} \mathrm{P}<0.05$ and ${ }^{* * *} \mathrm{P}<0.01$, as compared with the $\mathrm{A} \beta 25$-35-treated group. LDH, lactate dehydrogenase.

cells were round and intact with clear dark blue stained nuclei. However, obvious hippocampal histopathological damage was demonstrated in the APP/PS1 model group. The pyramidal layered structure was disintegrated and neuronal loss was detected in the CA1 region. Neurons exhibited pyknotic nuclei with a shrunken or irregular shape. Following GSPA or donepezil hydrochloride oral administration for 2 months 
A
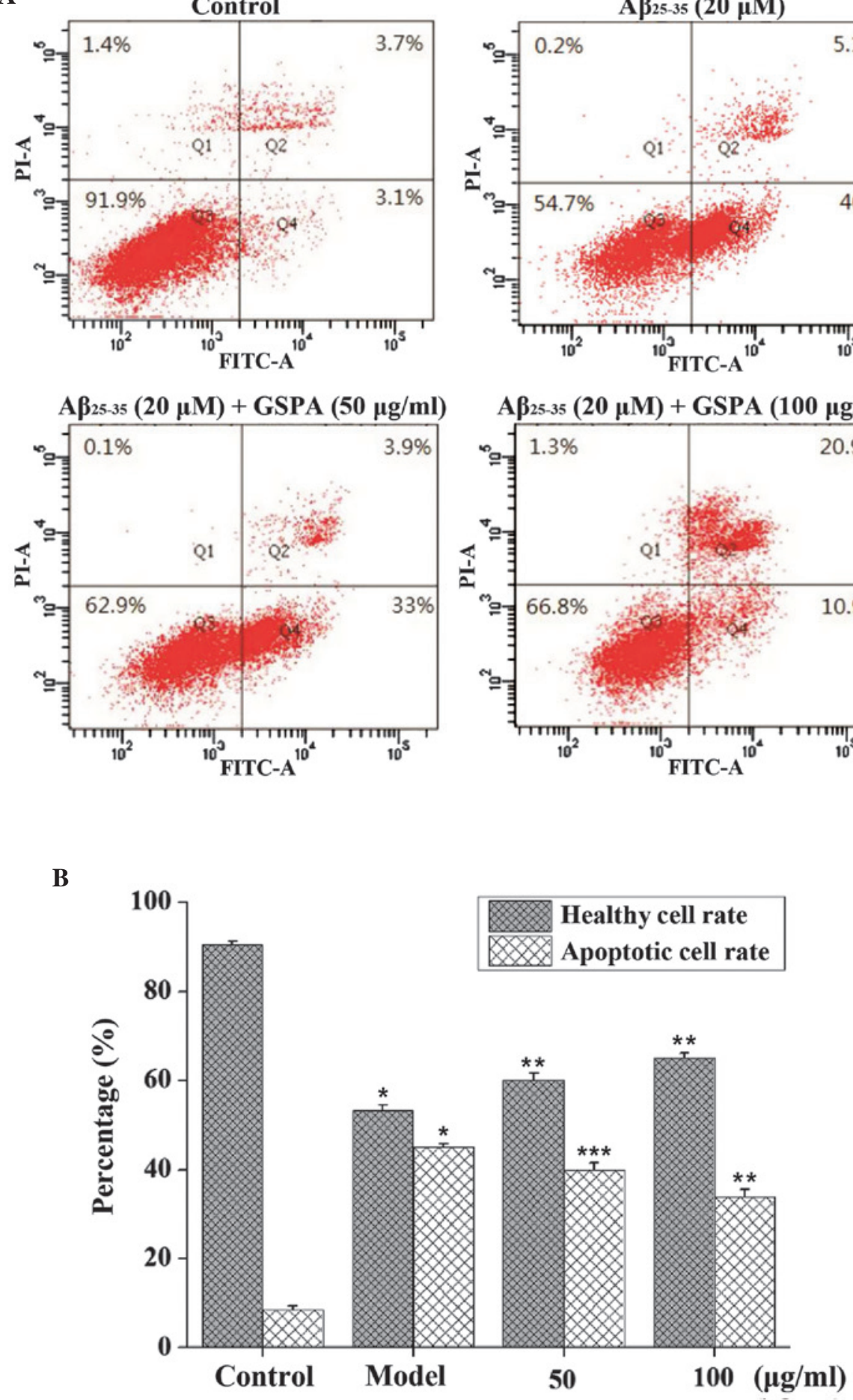

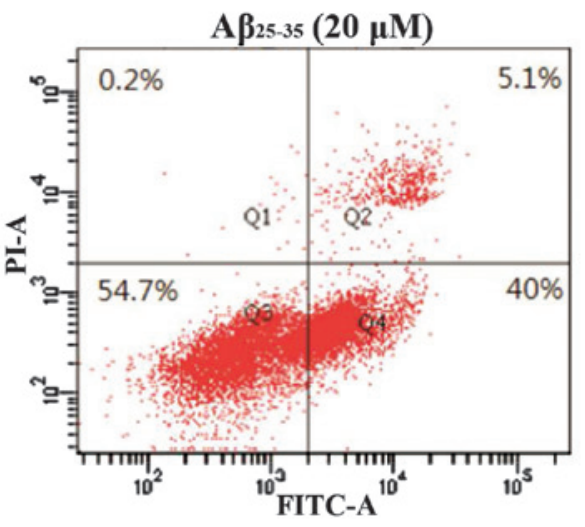

A $\beta_{25-35}(20 \mu M)+$ GSPA $(100 \mu \mathrm{g} / \mathrm{ml})$

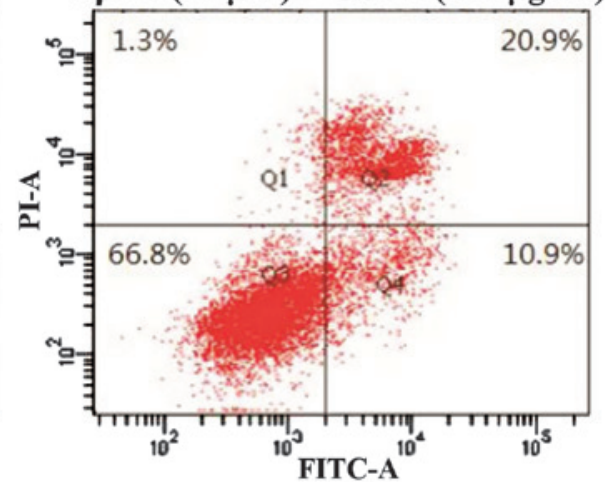

50

Figure 4.GSPA administration reduced A $\beta 25$-35-induced apoptosis. (A) Individual values (\%) are listed in representative dot plots and living PC12 cells were gated as shown in the fluorescence-activated cell sorting histograms for control PC12 cells, PC12 cells exposed to $20 \mu \mathrm{M} \mathrm{A} \beta 25-35,20 \mu \mathrm{M} \mathrm{A} \beta 25-35+50 \mu \mathrm{g} / \mathrm{ml} \mathrm{GSPA}$ and $20 \mu \mathrm{M} \mathrm{A} \beta 25-35+100 \mu \mathrm{g} / \mathrm{ml}$ GSPA. (B) A decrease in annexin-positive, PI-negative cells (lower right quadrant) and annexin-positive, PI-positive cells (higher right quadrant) was detected, which is indicative of reduced apoptosis. The increase in annexin-negative and PI-negative cells (lower left quadrant) is indicative of healthy non-apoptotic cells. Data are expressed as the mean \pm standard error of the mean $(\mathrm{n}=3)$. " $\mathrm{P}<0.01$, as compared with the control group; ${ }^{* *} \mathrm{P}<0.01$ and ${ }^{* * *} \mathrm{P}<0.05$, as compared with the A $\beta 25-35$-treated group. GSPA, grape seed proanthocyanidin; A $\beta 25-35$, amyloid $\beta 25-35$ peptide, PI, propidium iodide; FITC, fluorescein isothiocyanate.

these abnormalities were attenuated, as compared with the APP/PS1 model group. Cell morphology was regular, the cells were arranged more neatly and tightly, and cell nuclei stained clear. The APP/PS1-treated high dose GSPA group exhibited a stronger attenuation of these abnormalities, as compared with the low group, suggesting a concentration-dependent effect (Fig. 7).

Congo red was used to stain the amyloid plaques in the hippocampus of APP/PS1 double transgenic mice. The results demonstrated that amyloid plaques were distributed in the 
molecular layer of the hippocampus, and rare amyloid plaques were detected in the pyramidal cell layer. Amyloid plaques exhibited a light red dispersion without distinct boundaries and plaque staining was demonstrated to be denser in the hippocampi of the APP/PS1 model group, as compared with the hippocampi of the control group. The molecular layer exhibited an increased percentage of positive amyloid plaque areas, as compared with the control group. Plaque staining of APP/PS1 in the donepezil group and the low dose and high dose GSPA groups were lighter after GSPA or donepezil hydrochloride oral administration for 2 months. Positively stained areas of amyloid plaques were markedly reduced, as compared with the APP/PS1 model group (Fig. 8). The results suggest that GSPA is able to alleviate amyloid plaques in the hippocampus of APP/PS1 double transgenic mice.

Treatment with GSPA decreases APP and Tau protein expression levels in the hippocampi of APP/PSI double transgenic mice. Western blot analyses of APP and tau protein expression levels are shown in Fig. 9. Low APP and tau protein expression levels were detected in the control group. Significantly increased APP and tau protein expression levels were detected in the hippocampi of mice in the APP/PS1 model group $(\mathrm{P}<0.05$ and $\mathrm{P}<0.01$, respectively). Treatment with oral donepezil hydrochloride for 2 months significantly decreased APP and tau protein expression levels in the hippocampi of the APP/PS1 donepezil group, as compared with the APP/PS1 model group $(\mathrm{P}<0.01$ and $\mathrm{P}<0.05$, respectively). Furthermore, 2-month administration of oral GSPA significantly decreased APP and tau protein expression levels in the hippocampi of mice in the APP/PS1-treated high dose group, as compared with the APP/PS1 model group $(\mathrm{P}<0.05)$. The results suggest that GSPA is able to decrease APP and Tau protein expression levels in the hippocampi of APP/PS1 double transgenic mice.

Treatment with GSPA decreases PS-1 mRNA expression levels in the hippocampi of APP/PS1 double transgenic mice. Reverse transcription-quantitative polymerase chain reaction analysis of PS-1 mRNA expression levels was performed, as shown in Fig. 10. PS-1 mRNA expression levels were significantly increased in the APP/PS1 model group, as compared with the control group $(\mathrm{P}<0.01)$. PS-1 expression levels in the APP/PS1 donepezil and high dose GSPA groups were significantly decreased, as compared with the APP/PS1 model group (both $\mathrm{P}<0.01$ ). The results suggest that GSPA is able to decrease PS-1 mRNA expression levels in the hippocampi of APP/PS1 double transgenic mice.

\section{Discussion}

$\mathrm{AD}$ is a growing public health concern with devastating impacts. The disease is characterized by the hallmarks of $\mathrm{A} \beta$ peptide accumulation with hyperphosphorylation and aggregation of tau protein. Previous studies have indicated that the accumulation of neurotoxic $A \beta$ peptides has a causal role in $\mathrm{AD}$ dementia and memory deficits in the $\mathrm{Tg} 2576$ mouse AD model $(32,33)$. It has also been demonstrated that certain GSPEs may interfere with the aggregations of synthetic A $\beta$ peptides in vitro (34). Furthermore, according to the results

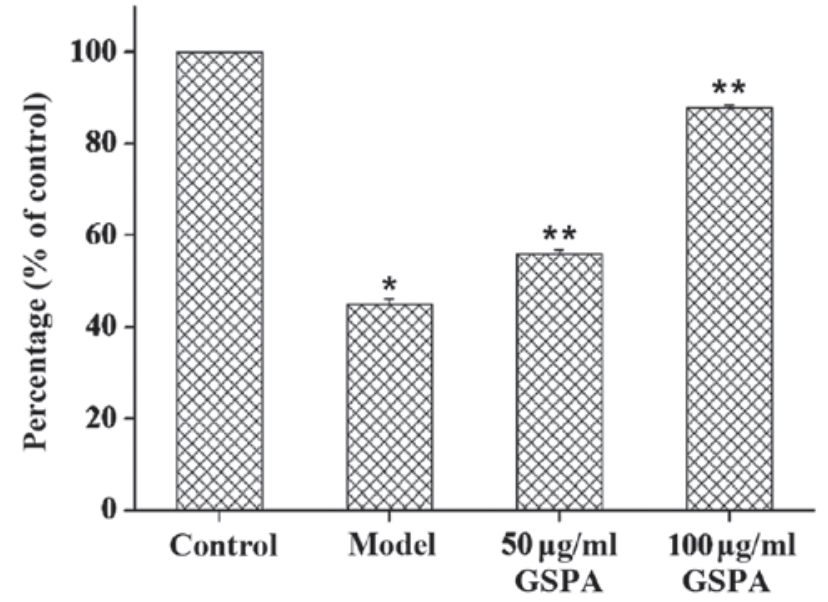

Figure 5. Grape seed proanthocyanidin suppressed mitochondrial membrane depolarization. Reduced rhodamine 123 fluorescence is indicative of mitochondrial membrane depolarization. Data are expressed as the mean \pm standard error of the mean $(n=3)$. ${ }^{*} \mathrm{P}<0.01$ compared to the control group; ${ }^{* *} \mathrm{P}<0.01$ compared to the $\mathrm{A} \beta 25-35$ model group.
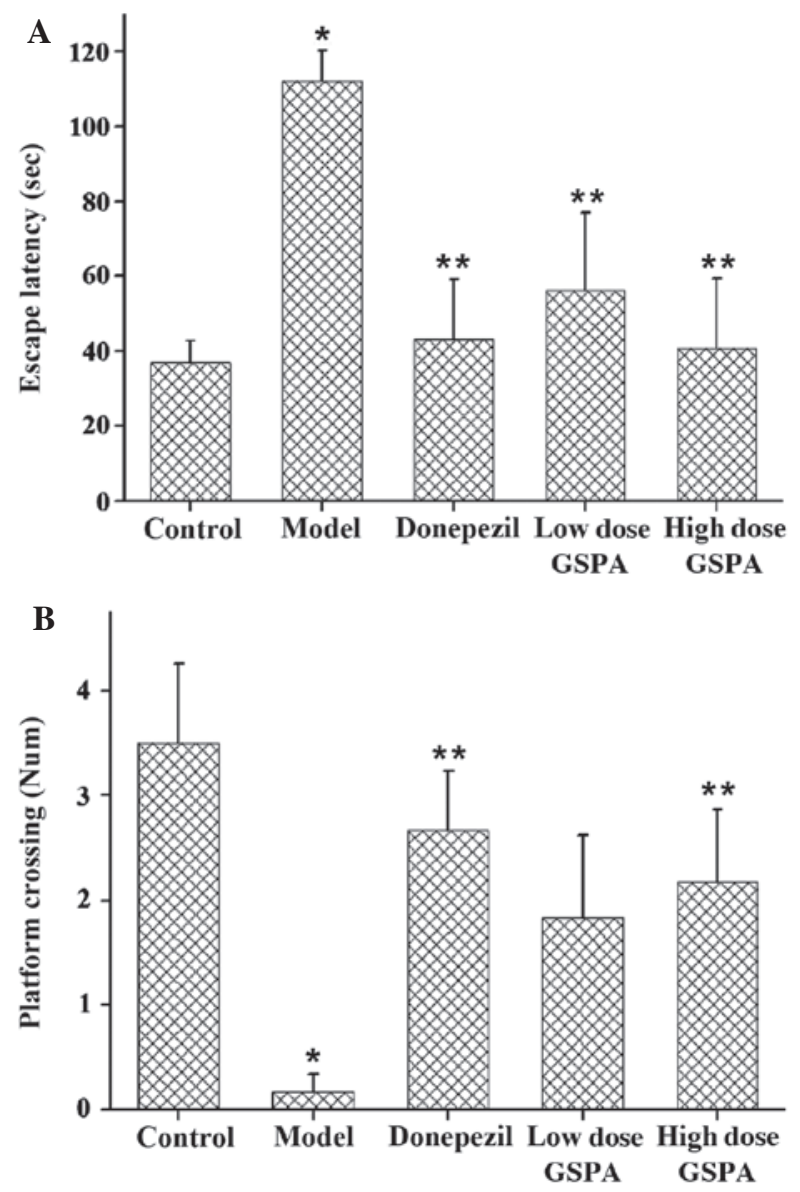

Figure 6. Comparisons of (A) average escape latency and (B) platform crossing in the spatial probe trials of amyloid precursor protein/ presenilin-1 heterozygous mouse model groups. Data are expressed as the mean \pm standard error of the mean $(n=6)$. ${ }^{*} \mathrm{P}<0.01$, as compared with the control group; ${ }^{* *} \mathrm{P}<0.05$, as compared with the model group. GSPA, grape seed proanthocyanidin.

of a previous binding assay, GSPE is capable of inhibiting tau peptide polymerization and scattering pre-aggregated tau peptide (35). 
Table II. Improved learning ability in amyloid precursor protein/presenilin-1 double transgenic mice treated with grape seed proanthocyanidin (GSPA), as determined by the Morris water maze test.

Time taken to find the platform (sec)

\begin{tabular}{lccccc}
\cline { 2 - 5 } Group & Day 1 & Day 2 & Day 3 & Day 4 & Day 5 \\
\hline Control & $117.50 \pm 2.50$ & $75.83 \pm 20.04$ & $67.17 \pm 23.70$ & $58.17 \pm 20.02$ & $52.67 \pm 11.11$ \\
Model & $120.00 \pm 0.00$ & $117.00 \pm 3.00$ & $102.50 \pm 11.34$ & $114.17 \pm 5.83$ & $107.17 \pm 8.64^{\mathrm{a}}$ \\
Donepezil & $120.00 \pm 0.00$ & $102.33 \pm 17.67$ & $81.67 \pm 13.64$ & $78.83 \pm 18.36$ & $57.67 \pm 14.05^{\mathrm{b}}$ \\
Low GSPA & $120.00 \pm 0.00$ & $97.67 \pm 7.31$ & $88.33 \pm 13.18$ & $81.67 \pm 10.84$ & $70.17 \pm 8.66^{\mathrm{b}}$ \\
High GSPA & $120.00 \pm 0.00$ & $80.00 \pm 14.09$ & $82.50 \pm 13.20$ & $74.50 \pm 8.72^{\mathrm{b}}$ & $67.83 \pm 3.96^{\mathrm{b}}$ \\
\hline
\end{tabular}

Data are expressed as the mean \pm standard error of the mean. ${ }^{\mathrm{a}} \mathrm{P}<0.05$, as compared with the control group; ${ }^{\mathrm{b}} \mathrm{P}<0.05$, as compared with the model group.

A

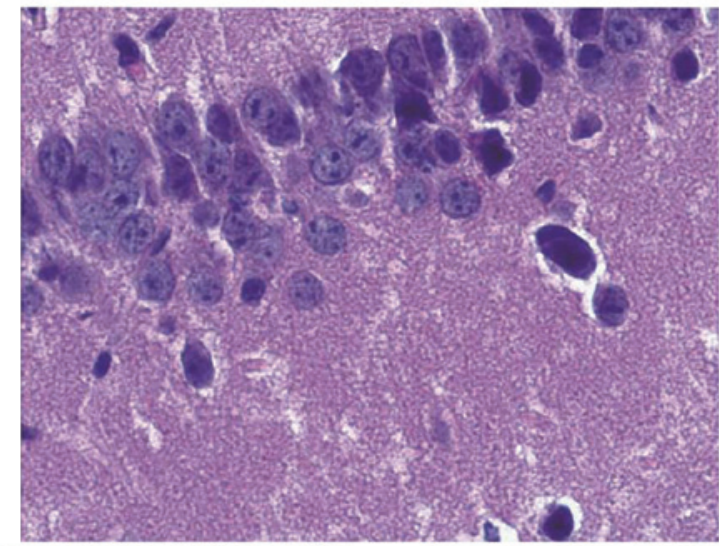

B

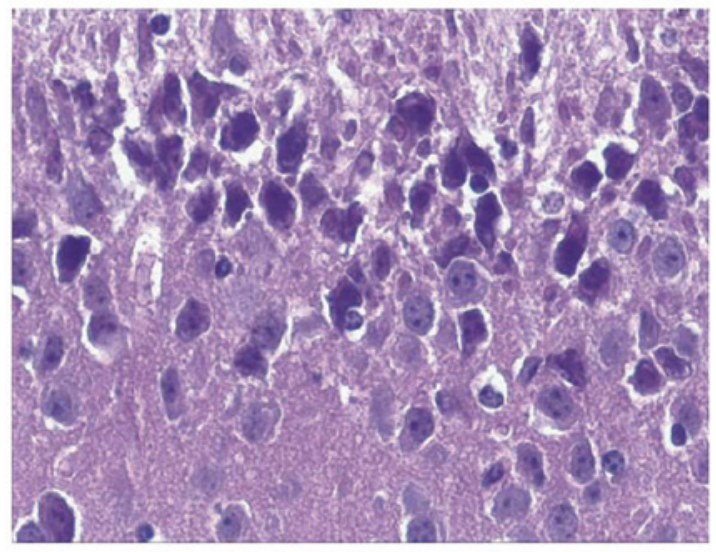

D

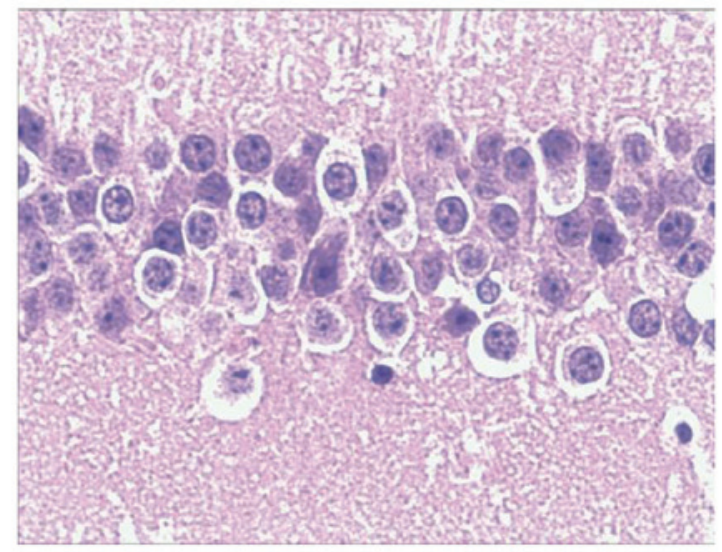

C

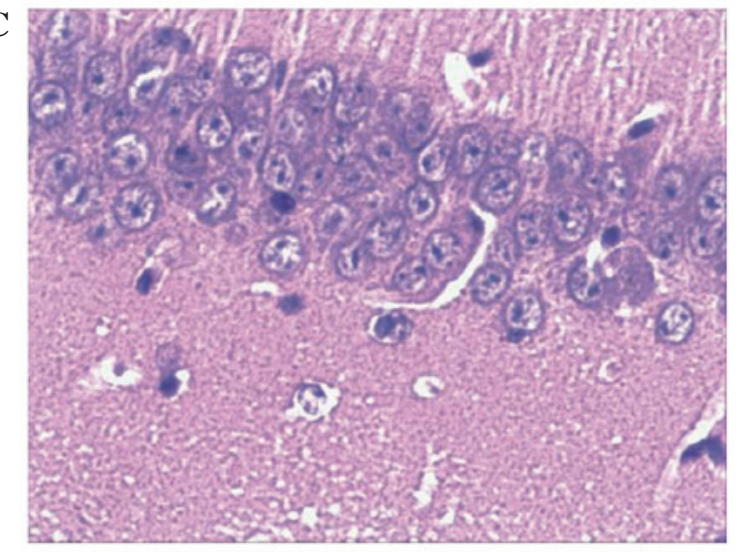

$\mathbf{E}$

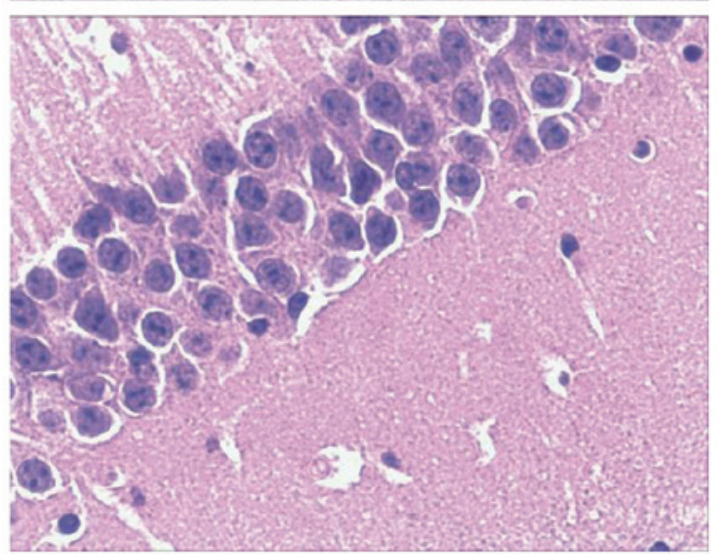

Figure 7. Hematoxylin and eosin staining (magnification, $x$ 400) of the (A) control; (B) APP/PS1 model; (C) APP/PS1 plus donepezil; (D) APP/PS1 plus low dose GSPA (50 mg/kg/day); and (E) APP/PS1 plus high dose GSPA (100 mg/kg/day) groups. APP, amyloid precursor protein; PS1, presenilin-1; GSPA, grape seed proanthocyanidin. 
$\mathbf{A}$

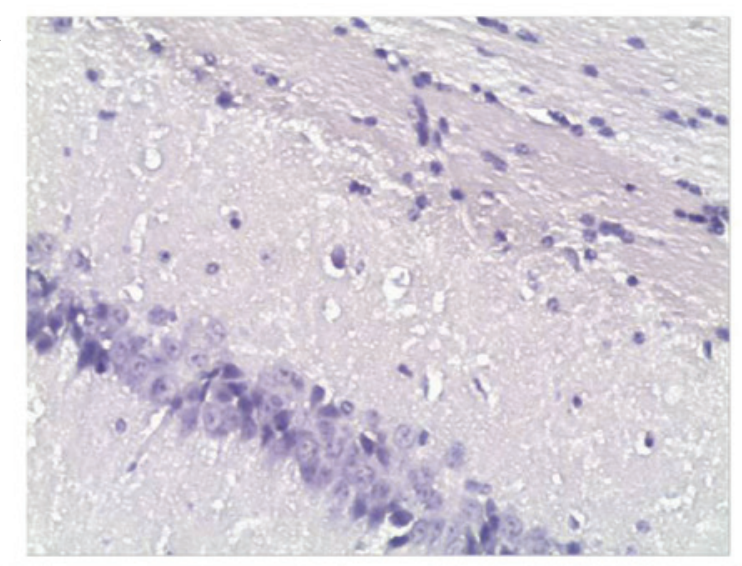

$\mathbf{B}$

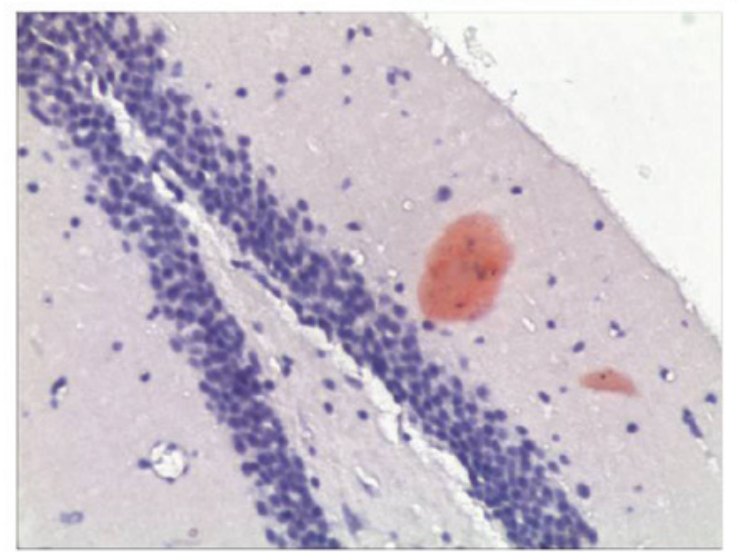

D

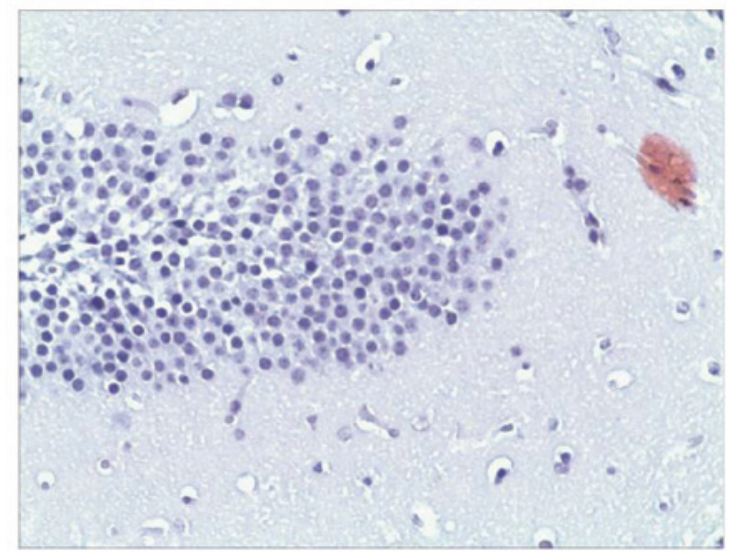

C

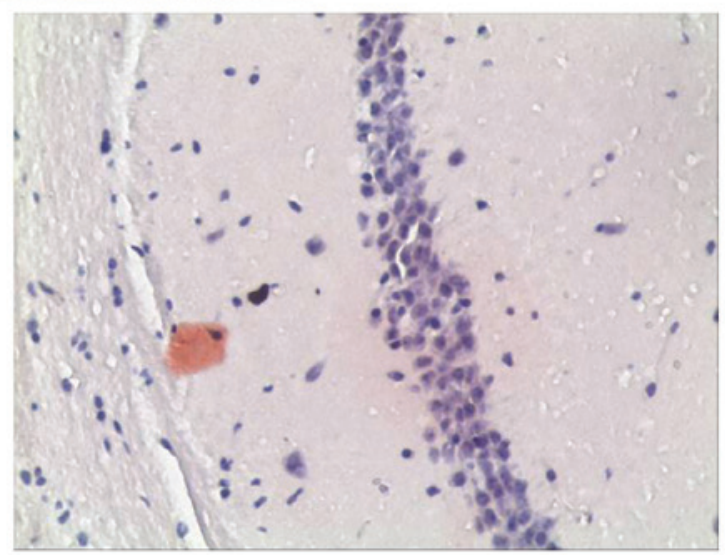

$\mathbf{E}$

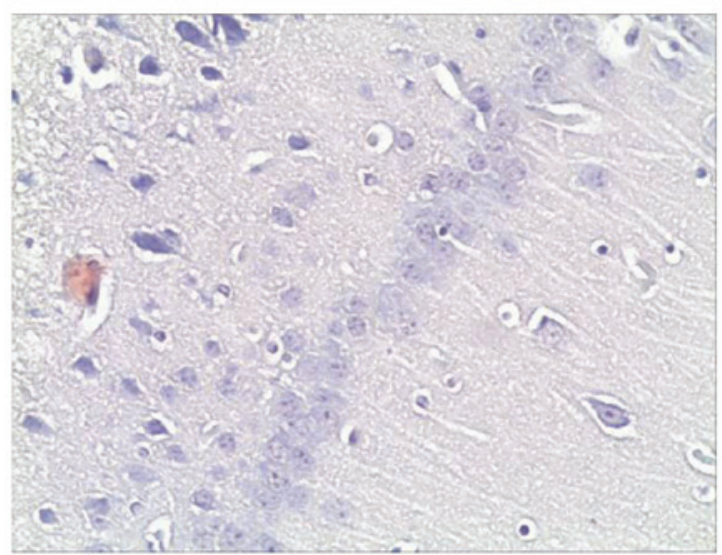

Figure 8. Congo red staining (magnification, x200) of the (A) control; (B) APP/PS1 model; (C) APP/PS1 plus donepezil; (D) APP/PS1 plus low dose GSPA (50 mg/kg/day); and (E) APP/PS1 plus high dose GSPA (100 mg/kg/day) groups. APP, amyloid precursor protein; PS1, presenilin-1; GSPA, grape seed proanthocyanidin.

Oxidative stress has an important role in the pathophysiology of AD. Previous studies have indicated that oxidative stress leads to apoptosis and excessive ROS facilitates neuronal apoptosis in $A \beta$-induced neuronal cell death $(36,37)$. Moreover, it has been demonstrated that the overproduction of $A \beta$ leads to $A \beta$-associated free-radical production and cell death $(37,38)$. These findings indicate that $\mathrm{A} \beta$ induces oxidative stress and vice versa, which leads to more oxidative damage, including membrane damage and reduced cell viability. When cell membranes are damaged, LDH levels increase. The present study demonstrated that GSPA is able to reverse A $\beta 25$-35-induced LDH leakage and decreased PC12 cell viability (39). These results demonstrated that GSPA is capable of scavenging oxygen radicals. Therefore, the protective effect of GSPA against A 225-35 induced oxidative stress in PC12 cells may be due to enhanced anti-oxidant capacity and reduced accumulation of intracellular ROS.

Cell apoptosis has a central role in the pathogenesis of AD. Oxidative stress induces apoptotic cell death via the activation of caspase 3 (40). In the present study, Annexin V-FITC and PI double staining was used to investigate basal apoptosis rates. PC12 cells treated with extracellular A $325-35$ at concentrations of $20 \mu \mathrm{M}$ exhibited significantly increased levels of apoptosis, as compared with the control cells. These data suggested that A 25-35 may increase caspase 3 expression levels and induce oxidative stress, leading to apoptosis. However, treatment with 50 or $100 \mu \mathrm{g} / \mathrm{ml} \mathrm{GSPA}$ significantly decreased cell apoptosis. 
A

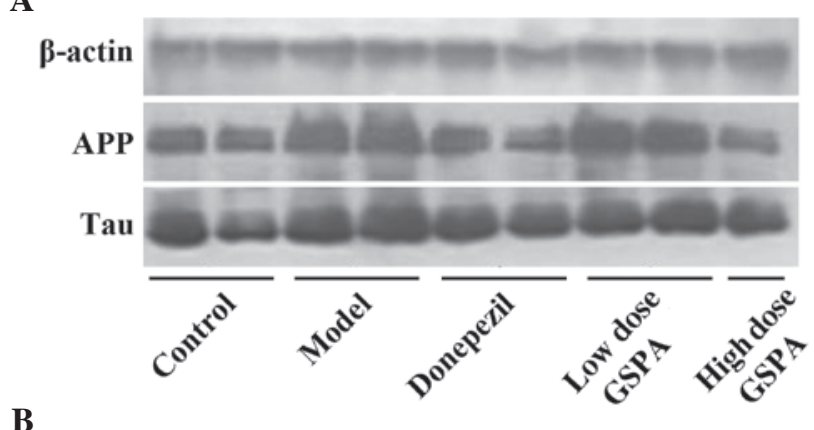

B

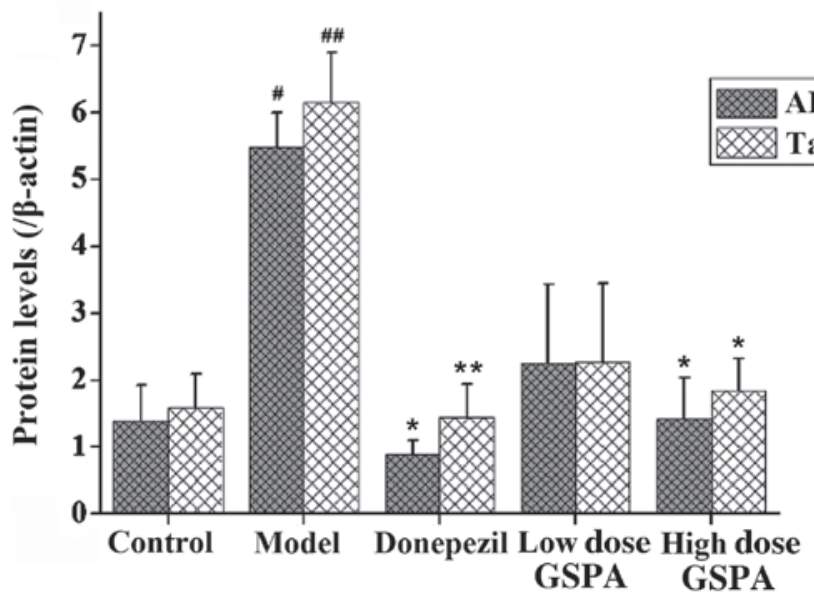

Figure 9. (A) Western blot analysis of APP and Tau protein among the control, APP/PS1 model, APP/PS1 plus donepezil and APP/PS1 plus low (50 mg/kg/day) and high (100 mg/kg/day) dose GSPA groups, respectively. (B) Quantitative comparison of the protein levels of APP and Tau among the group, relative to $\beta$-actin. Data are expressed as the mean \pm standard error of the mean $(\mathrm{n}=6)$ mice. ${ }^{\#} \mathrm{P}<0.05$ and ${ }^{\# \#} \mathrm{P}<0.01$, as compared with the control group; ${ }^{*} \mathrm{P}<0.05$ and ${ }^{* *} \mathrm{P}<0.01$, as compared with the APP/PS1 model group.

This result may be associated with decreasing levels of caspase 3 and oxidative stress.

A significant reduction of the mitochondrial $\Psi \mathrm{m}$ can trigger apoptosis through the release of caspase 3. Previous studies have demonstrated that A $325-35$ leads to oxidative stress and mitochondrial damage due to the loss of mitochondrial $\Psi \mathrm{m}(41,42)$. Consistent with a previous study (43), the results of the present study demonstrated a significant decrease in mitochondrial $\Psi \mathrm{m}$ following stimulation with extracellular A $\beta 25-35$, as compared with the control cells, using rhodamine 123 fluorescence. Pretreatment of PC12 cells with GSPA reversed the mitochondrial $\Psi \mathrm{m}$ depolarization induced by $A \beta 25-35$, which suggested that GSPA may prevent cell death by blocking the activation of the mitochondrial apoptosis pathway.

In the present study, the significant cytotoxic effect of A $325-35$ on PC12 cells was demonstrated by the CCK-8 assay, and Annexin V-FITC and PI double staining with flow cytometry. It was hypothesized that activation of caspase 3 induced apoptosis. This result may be associated with oxidative stress and stress-related damage to the mitochondria or its membranes. Notably, GSPA may reverse the A $\beta 25-35$-induced increase of ROS and decrease of mitochondrial $\Psi \mathrm{m}$, which ultimately protected the cells from apoptosis.

The results of the present study also demonstrated that oral administration of GSPA significantly reduced the

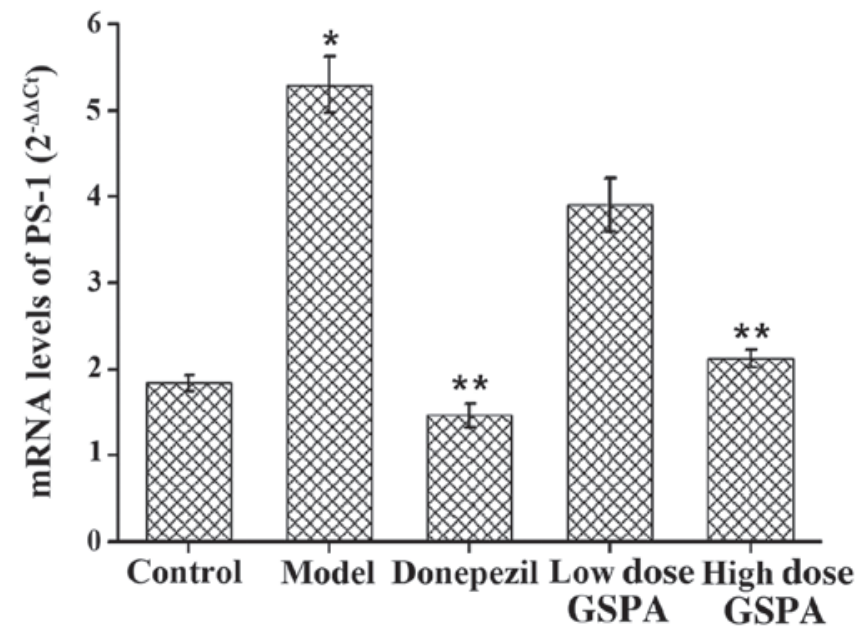

Figure 10. Reverse transcription-quantitative polymerase chain reaction analysis. Comparison of PS-1 mRNA expression levels among the control, APP/PS1 model, APP/PS1 plus donepezil and APP/PS1 plus low (50 mg/kg/day) and high (100 mg/kg/day) dose GSPA groups, respectively. Data are expressed as the mean \pm standard error of the mean $(n=6) .{ }^{*} \mathrm{P}<0.01$, as compared with the control group; ${ }^{* *} \mathrm{P}<0.01$, as compared with the APP/PS1 model group. APP, amyloid precursor protein; PS1, presenilin-1; GSPA, grape seed proanthocyanidin.

accumulation of $\mathrm{A} \beta$ peptides, alleviated the hyperphosphorylation of tau protein and improved learning behavior and memory in APP/PS1 double transgenic mice. The mechanisms underlying these phenomenon may involve the downregulation of $A \beta$ accumulation and the disruption of tau protein hyperphosphorylation in the brain.

APP/PS1 mice exhibited a significant loss of learning, cognition and memory behavior in the present study, as compared with the control mice. These results are consistent with previous studies, which have demonstrated APP/PS1 mice with early onset brain amyloidosis, and synaptic changes in the hippocampus and brain cortex $(44,45)$. The MWM test is a well-known behavioral task which is used to assess oriented navigation and spatial probe memory capacity (46). During the spatial probe phase of the MWM test in the present study, the GSPA treatment group exhibited significant decreased escape latency periods and an increased number of platform crossing incidences, as compared with APP/PS1 model group. These data demonstrated that the GSPA-treated APP/PS1 mice exhibited an enhanced capacity for learning, cognition and memory. We hypothesize that this effect may be induced by a reduction in $A \beta$ in the brain, as excessive toxic $A \beta$ has been demonstrated to induce the formation of $A \beta$ plaques (47). HE and Congo red staining was used to detect amyloidosis in the hippocampi of the mice. The APP/PS1 model group exhibited a significant increase in the number of $\mathrm{A} \beta$ plaques in the hippocampus, as compared with the control group. Notably, GSPA treatment significantly ameliorated these $\mathrm{A} \beta$ plaques.

The results of the present study have demonstrated that mutations in the APP and PS genes increase oxidative stress in the neurons of APP/PS1 mice, and oxidative stress is mediated by $A \beta$. The $A \beta$ protein is critical to the pathogenesis of $\mathrm{AD}(48,49)$; however, the precise mechanism underlying the pathogenesis of AD is yet to be fully elucidated. Therefore, 
one of the aims of preventive or early treatment of AD is to decrease oxidative stress. A $\beta$ peptides are produced from the APP, which are cleaved by $\beta$ - and $\gamma$ - secretases into amino acid peptides within the cerebral cortex and hippocampus (3). $\gamma$-secretase is an intramembrane aspartyl protease that is critically involved in AD via the proteolysis of APP, which generates the pathogenic and amyloid plaque-forming A $\beta 1-42$ peptide (50). PS-1 is a member of a multi-subunit intramembranous protein complex with $\gamma$-secretase; thus, a reduction in PS-1 mRNA expression levels directly suppresses the activation of $\gamma$-secretase. PS-1 also stimulates tau protein aggregation into abnormally hyperphosphorylated tau via A $\beta$ (51). Therefore, it was hypothesized that restraining PS-1 mRNA and APP protein expression levels via decreased oxidative stress may be a viable strategy for AD therapy. In the present study, western blot and RT-qPCR analyses were used to confirm that treatment with GSPA significantly decreased PS-1 mRNA expression levels. The effects of GSPA on PS-1 mRNA expression and $\gamma$-secretase activation may interrupt the generation of the $A \beta$ peptide. Moreover, the results of the present study demonstrated that oral treatment with GSPA significantly reduced the accumulation of APP and insoluble tau in the brains of APP/PS1 mice. GSPA may function as a strong antioxidant by decreasing the levels of APP and tau protein. This phenomenon may be associated with: i) the strong antioxidant action of GSPA suppressing the activation of $\gamma$ - secretases to reduce A $\beta$ production; or ii) GSPA directly interfering with the aggregation of $\mathrm{A} \beta$ or dissociated aggregation of $A \beta$ into oligomers, which may reduce oxidative stress and restore the antioxidant balance.

In conclusion, the present preclinical study demonstrated that GSPA treatment attenuates APP production or accumulation, interrupts the aggregation of neurotoxic $A \beta$ and decreases hyperphosphorylated tau deposition. Notably, GSPA treatment improved the cognition and memory capacity of a APP/PS1 double transgenic mouse model. The results of the present in vitro biochemistry studies and in vivo preclinical studies suggested that GSPA administration may benefit AD via two, non-exclusive mechanisms: i) enhanced antioxidant function and ii) downregulation of caspase 3-mediated aggregation of $\mathrm{A} \beta$ in response to oxidative stress. The results of the present study provide support for continuing the development of GSPA for the treatment and/or prevention of $\mathrm{AD}$.

\section{Acknowledgements}

The present study was supported by the Special Funds from Central Finance of China in Support of the Development of Local Colleges and University [grant no. 276 (2014)]. This research was also supported in part by BannerBio Nutraceuticals, Inc. The funding bodies had no role in study design, data collection and analysis, decision to publish, or preparation of the manuscript.

\section{References}

1. Blennow K, de Leon MJ and Zetterberg H: Alzheimer's disease. Lancet 368: 387-403, 2006.

2. Nelson PT, Braak H and Markesbery WR: Neuropathology and cognitive impairment in Alzheimer disease: A complex but coherent relationship. J Neuropathol Exp Neurol 68: 1-14, 2009.
3. Haass C and Selkoe DJ: Soluble protein oligomers in neurodegeneration: Lessons from the Alzheimer's amyloid beta-peptide. Nat Rev Mol Cell Biol 8: 101-112, 2007.

4. Li MH, Jang JH, Sun B and Surh YJ: Protective effects of oligomers of grape seed polyphenols against beta-amyloid-induced oxidative cell death. Ann. NY Acad Sci 1030: 317-329, 2004.

5. Frykman S, Hur JY, Frånberg J, Aoki M, Winblad B, Nahalkova J, Behbahani $\mathrm{H}$ and Tjernberg LO: Synaptic and endosomal localization of active $\gamma$-secretase in rat brain. PLoS One 5: e8948, 2010.

6. Smolarkiewicz M, Skrzypczak T and Wojtaszek P: The very many faces of presenilins and the $\gamma$-secretase complex. Protoplasma 250: 997-1011, 2013.

7. Hasegawa M, Morishima-Kawashima M, Takio K, Suzuki M, Titani $\mathrm{K}$ and Ihara Y: Protein sequence and mass spectrometric analyses of tau in the Alzheimer's disease brain. J Biol Chem 267: 17047-17054, 1992.

8. Crack PJ and Taylor JM: Reactive oxygen species and the modulation of stroke. Free Radic Biol Med 38: 1433-1444, 2005.

9. Hu JF, Chu SF, Ning N, Yuan YH, Xue W, Chen NH and Zhang JT: Protective effect of (-)clausenamide against Abeta-induced neurotoxicity in differentiated PC12 cells. Neurosci Lett 483: 78-82, 2010.

10. Li G, Ma R, Huang C, Tang Q, Fu Q, Liu H, Hu B and Xiang J: Protective effect of erythropoietin on beta-amyloid-induced PC12 cell death through antioxidant mechanisms. Neurosci Lett 442: 143-147, 2008a.

11. Zhang HY, Liu YH, Wang HQ, Xu JH and Hu HT: Puerarin protects PC12 cells against beta-amyloid-induced cell injury. Cell Biol Int 32: 1230-1237, 2008.

12. Crack PJ, Cimdins K, Ali U, Hertzog PJ and Iannello RC: Lack of glutathione peroxidase-1 exacerbates Abeta-mediated neurotoxicity in cortical neurons. J Neural Transm 113: 645-657, 2006.

13. Petersen RC: Mild cognitive impairment: Transition between aging and Alzheimer's disease. Neurologia 15: 93-101, 2000.

14. Rinaldi P, Polidori MC, Metastasio A, Mariani E, Mattioli P, Cherubini A, Catani M, Cecchetti R, Senin U and Mecocci P: Plasma antioxidants are similarly depleted in mild cognitive impairment and in Alzheimer's disease. Neurobiol Aging 24: 915-919, 2003.

15. Guidi I, Galimberti D, Lonati S, Novembrino C, Bamonti F, Tiriticco M, Fenoglio C, Venturelli E, Baron P, Bresolin N and Scarpini E: Oxidative imbalance in patients with mild cognitive impairment and Alzheimer's disease. Neurobiol Aging 27: 262-269, 2006.

16. Chen JX and Yan SD: Pathogenic role of mitochondrial amyloidbeta peptide. Expert Rev Neurother 7: 1517-1525, 2007.

17. Lee SY,Lee JW, Lee H, Yoo HS, Yun YP, Oh KW, Ha TY and Hong JT: Inhibitory effect of green tea extract on beta-amyloid-induced PC12 cell death by inhibition of the activation of NF-kappaB and ERK/p38 MAP kinase pathway through antioxidant mechanisms. Brain Res Mol Brain Res 140: 45-54, 2005.

18. Wang J, Ho L, Zhao Z, Seror I, Humala N, Dickstein DL, Thiyagarajan M, Percival SS, Talcott ST and Pasinetti GM: Moderate consumption of Cabernet Sauvignon attenuates Abeta neuropathology in a mouse model of Alzheimer's disease. FASEB J 20: 2313-2320, 2006.

19. Ono K, Condron MM, Ho L, Wang J, Zhao W, Pasinetti GM and Teplow DB: Effects of grape seed-derived polyphenols on amyloid beta-protein self-assembly and cytotoxicity. J Biol Chem 283: 32176-32187, 2008.

20. Crowe A, Ballatore C, Hyde E, Trojanowski JQ and Lee VM: High throughput screening for small molecule inhibitors of heparin-induced tau fibril formation. Biochem Biophys Res Commun 358: 1-6, 2007.

21. Pickhardt M, von Bergen M, Gazova Z, Hascher A, Biernat J, Mandelkow EM and Mandelkow E: Screening for inhibitors of tau polymerization. Curr Alzheimer Res 2: 219-226, 2005.

22. Wang J, Santa-Maria I, Ho L, Ksiezak-Reding H, Ono K, Teplow DB and Pasinetti GM: Grape derived polyphenols attenuate tau neuropathology in a mouse model of Alzheimer's disease. J Alzheimers Dis 22: 653-661, 2010.

23. Okello EJ, Savelev SU and Perry EK: In vitro anti-beta-secretase and dual anti-cholinesterase activities of Camellia sinensis L. (tea) relevant to treatment of dementia. Phytother Res 18: 624-627, 2004.

24. Wang J, Ho L, Zhao W, Ono K, Rosensweig C, Chen L, Humala N, Teplow DB and Pasinetti GM: Grape-derived polyphenolics prevent Abeta oligomerization and attenuate cognitive deterioration in a mouse model of Alzheimer's disease. J Neurosci 28: 6388-6392, 2008 
25. Li J, Zhang HL, Wang Z, Liang YM, Jiang L, Ma W and Yang DP: Determination content of the antidepressant extraction and analysis the trace elements from Morinda officinalis. Zhong Yao Cai 31: 1337-1340, 2008b (In Chinese).

26. Labbé JF, Lefèvre T, Guay-Bégin AA and Auger M: Structure and membrane interactions of the $\beta$-amyloid fragment 25-35 as viewed using spectroscopic approaches. Phys Chem Chem Phys 15: 7228-7239, 2013.

27. Emoto K, Toyama-Sorimachi N, Karasuyama H, Inoue K and Umeda M: Exposure of phosphatidylethanolamine on the surface of apoptotic cells. Exp Cell Res 232: 430-434, 1997.

28. Scaduto RC Jr and Grotyohann LW: Measurement of mitochondrial membrane potential using fluorescent rhodamine derivatives. Biophys J 76: 469-477, 1999.

29. Lee MR, Yun BS, Park SY, Ly SY, Kim SN, Han BH, and Sung CK: Anti-amnesic effect of Chong-Myung-Tang on scopolamine-induced memory impairments in mice. J Ethnopharmacol 132: 70-74, 2010.

30. Livak KJ and Schmittgen TD: Analysis of relative gene expression data using real-time quantitative PCR and the $2^{-\Delta \Delta C}$ method. Methods 25: 402-408, 2001.

31. Chen S, Cheng AC, Wang MS and Peng X: Detection of apoptosis induced by new type gosling viral enteritis virus in vitro through fluorescein annexin V-FITC/PI double labeling. World J Gastroenterol 14: 2174-2178, 2008.

32. Cleary JP, Walsh DM, Hofmeister JJ, Shankar GM, Kuskowski MA, Selkoe DJ and Ashe KH: Natural oligomers of the amyloid-beta protein specifically disrupt cognitive function. Nat Neurosci 8: 79-84, 2005.

33. Klyubin I, Walsh DM, Lemere CA, Cullen WK, Shankar GM, Betts V, Spooner ET, Jiang L, Anwyl R, Selkoe DJ and Rowan MJ: Amyloid beta protein immunotherapy neutralizes Abeta oligomers that disrupt synaptic plasticity in vivo. Nat Med 11: 556-561, 2005.

34. Porat Y, Abramowitz A and Gazit E: Inhibition of amyloid fibril formation by polyphenols: Structural similarity and aromatic interactions as a common inhibition mechanism. Chem Biol Drug Des 67: 27-37, 2006.

35. Ho L, Yemul S, Wang J and Pasinetti GM: Grape seed polyphenolic extract as a potential novel therapeutic agent in tauopathies. J Alzheimers Dis 16: 433-439, 2009.

36. Bonda DJ, Wang X, Perry G, Nunomura A, Tabaton M, Zhu X and Smith MA: Oxidative stress in Alzheimer disease: A possibility for prevention. Neuropharmacology 59: 290-294, 2010.

37. Kadowaki H, Nishitoh H, Urano F, Sadamitsu C, Matsuzawa A, Takeda K, Masutani H, Yodoi J, Urano Y, Nagano T and Ichijo H: Amyloid beta induces neuronal cell death through ROS-mediated ASK1 activation. Cell Death Differ 12: 19-24, 2005.
38. Sponne I,Fifre A,DrouetB,Klein C,Koziel V,Pincon-Raymond M Olivier JL, Chambaz J and Pillot T: Apoptotic neuronal cell death induced by the non-fibrillar amyloid-beta peptide proceeds through an early reactive oxygen species-dependent cytoskeleton perturbation. J Biol Chem 278: 3437-3445, 2003.

39. Zhang YM: Protective effect of quercetin on aroclor 1254-induced oxidative damage in cultured chicken spermatogonial cells. Toxicol Sci 88: 545-550, 2005.

40. Marques CA, Keil U, Bonert A, Steiner B, Haass C, Muller WE and Eckert A: Neurotoxic mechanisms caused by the Alzheimer's disease-linked Swedish amyloid precursor protein mutation: Oxidative stress, caspases, and the JNK pathway. J Biol Chem 278: 28294-28302, 2003

41. Green DR and Reed JC: Mitochondria and apoptosis. Science 281: 1309-1312, 1998

42. Yankner BA, Dawes LR, Fisher S, Villa-Komaroff L, Oster-Granite ML and Neve RL: Neurotoxicity of a fragment of the amyloid precursor associated with Alzheimer's disease. Science 245: 417-420, 1989.

43. Jang JH and Surh YJ: Protective effect of resveratrol on beta-amyloid-induced oxidative PC12 cell death. Free Radic Biol Med 34: 1100-1110, 2003.

44. Hoxha E, Boda E, Montarolo F, Parolisi R and Tempia F: Excitability and synaptic alterations in the cerebellum of APP/PS1 mice. PLoS One 7: e34726, 2012.

45. Park SM, Shin JH, Moon GJ, Cho SI, Lee YB and Gwag BJ: Effects of collagen-induced rheumatoid arthritis on amyloidosis and microvascular pathology in APP/PS1 mice. BMC Neurosci 12: 106, 2011.

46. Sharma S, Rakoczy S and Brown-Borg H: Assessment of spatial memory in mice. Life Sci 87: 521-536, 2010.

47. Galimberti D and Scarpini E: Alzheimer's disease: From pathogenesis to disease-modifying approaches. CNS Neurol Disord Drug Targets 10: 163-174, 2011.

48. Lovell MA, Xie C, Xiong S and Markesbery WR: Protection against amyloid beta peptide and iron/hydrogen peroxide toxicity by alpha lipoic acid. J Alzheimers Dis 5: 229-239, 2003.

49. Butterfield DA, Castegna A, Lauderback CM and Drake J: Evidence that amyloid beta-peptide-induced lipid peroxidation and its sequelae in Alzheimer's disease brain contribute to neuronal death. Neurobiol Aging 23: 655-664, 2002.

50. Hass MR, Sato C, Kopan R and Zhao G: Presenilin: RIP and beyond. Semin Cell Dev Biol 20: 201-210, 2009.

51. Kong R, Chang S, Xia W and Wong ST: Molecular dynamics simulation study reveals potential substrate entry path into $\gamma$-secretase/presenilin-1. J Struct Biol 191: 120-129, 2015. 